\title{
New Middle Eastern Studies
}

Publication details, including guidelines for submissions: http://www.brismes.ac.uk/nmes/

\section{Review of Zeina B. Ghandour, A Discourse on Domination in Mandate Palestine: Imperialism, Property and Insurgency}

Author(s): Lauren Banko

To cite this article: Banko, Lauren, review of Zeina B. Ghandour, A Discourse on Domination in Mandate Palestine: Imperialism, Property and Insurgency (Abingdon and New York: Routledge, 2010), New Middle Eastern Studies, 1 (2011), <http://www.brismes.ac.uk/nmes/archives/456>.

To link to this article: http://www.brismes.ac.uk/nmes/archives/456

Online Publication Date: 15 June 2011

\begin{abstract}
Disclaimer and Copyright
The NMES editors and the British Society for Middle Eastern Studies make every effort to ensure the accuracy of all the information contained in the e-journal. However, the editors and the British Society for Middle Eastern Studies make no representations or warranties whatsoever as to the accuracy, completeness or suitability for any purpose of the content and disclaim all such representations and warranties whether express or implied to the maximum extent permitted by law. Any views expressed in this publication are the views of the authors and not the views of the Editors or the British Society for Middle Eastern Studies.
\end{abstract}

Copyright New Middle Eastern Studies, 2011. All rights reserved. No part of this publication may be reproduced, stored, transmitted or disseminated, in any form, or by any means, without prior written permission from New Middle Eastern Studies, to whom all requests to reproduce copyright material should be directed, in writing.

\section{Terms and conditions:}

This article may be used for research, teaching and private study purposes. Any substantial or systematic reproduction, re-distribution, re-selling, loan or sub-licensing, systematic supply or distribution in any form to anyone is expressly forbidden.

The publisher does not give any warranty express or implied or make any representation that the contents will be complete or accurate or up to date. The accuracy of any instructions, formulae and drug doses should be independently verified with primary sources. The publisher shall not be liable for any loss, actions, claims, proceedings, demand or costs or damages whatsoever or howsoever caused arising directly or indirectly in connection with or arising out of the use of this material. 


\title{
NeW MidDle EASTERN REVIEWS
}

\author{
A Discourse on Domination in Mandate Palestine: Imperialism, Property and \\ Insurgency \\ Zeina B. Ghandour
}

Abingdon and New York, Routledge, 2010, vii + 197 pp., £75, Hardback

ISBN 978-0415489935

\section{REVIEWED BY LAUREN BANKO}

PhD Candidate, Department of History, School of Oriental \& African Studies, University of London; e-mail: lauren.banko@soas.ac.uk

In the historiography of the Palestine Mandate, it remains rare to find a research monograph which does not focus heavily on the development of Palestinian nationalism, and few tell the history of this time period through the words of non-elite Palestinians. As the field of Palestinian studies slowly moves into an era of micro-histories, only a small handful of monographs written in English have been studies of non-elite experiences. These include the work of anthropologists Rosemary Sayigh and Ted Swedenberg which both use oral history sources extensively. However, both of these scholars still work within the worn discourses of a grand narrative of the development of nationalism in Palestine. Zeina Ghandour's $A$ Discourse on Domination in Mandate Palestine: Imperialism, Property and Insurgency presents a new and interdisciplinary perspective on the history of the Mandate and the Palestine Revolt by focusing specifically on British colonial domination through land, economic and religious policies, and the responses to it by non-elite Palestinians. Ghandour sets out to un-write the existing history of the Mandate and then re-write it with a totally different approach. In the field of Palestinian history, I can think of no other book that so completely embodies the tradition of postcolonial subaltern studies. Unlike Swedenberg, Ghandour does not portray the subaltern insurgent as a nationalist or attempt to explain how nationalist symbols and the nationalist narrative fit into the rebel's reasons for joining the Palestinian Revolt. Further, unlike most other books on the Mandate, A Discourse on Domination uses oral history and personal papers of the Palestinian rebels and, consequently, reveals their view of history. The rebels' view stands in stark contrast to very frank British official discourse. The latter discourse is constructed with the personal papers of mandatory officials, and these give the colonial view of the history of the Palestinian "natives."

Ghandour (in an often cheeky way) produces the colonial discourses of the British mandatory authorities in their own words and her intention is, in fact, not to shy away from the prominent cultural representations that are riddled through the British official and unofficial correspondence. In this way, she begins the book with a study of a sorely-lacking element in the field: comparing the British systems of colonialism in the Middle East, Africa and India and showing how these experiences heavily impacted the Palestine Administration, especially in the use of law and land legislation as a tool of control. The author continues in the chapter titled "'Unmarked and Undivided': Language, Law and Myth" with a discussion of land law and how cadastral surveys (or lack thereof) and maps created a type of colonial control over the Palestinian Arabs by denying them redress to claim land the administration expropriated as they drew new maps of the territory under Mandate. Historians have written about land and property law in Palestine under Ottoman and British rule, but not in the way 
Ghandour does. Land and property law, to Ghandour, is a system of control against the population of Palestine by the authorities, based on their experience with land policies in Great Britain and her colonial empire.

As for the Palestinian discourse on domination by the British, here again Ghandour draws on the tradition of subaltern studies. In contrast to other histories, she does not offer a meta-narrative of experiences of Palestinians from the 1920s until the end of the Mandate. Instead, using both Palestinian oral testimonies and a unique use of British archives, Ghandour historicises British officials' preoccupation with the Palestinian rebels in "Between Bazaar and Bungalow: A Rebellion without Rebels." In this way Ghandour answers the question, posed early in the book, of whether the subaltern spoke or was disobedient during the Mandate and if so, why was this subaltern absent from its histories? A truly refreshing part of the book is the focus on grassroots resistance to the British that began in earnest in the early 1930s. This resistance and the violence that it eventually endorsed are chronicled in three phases. Here, I take a small exception to the method of the author. The dividing of the period after 1935 is done in the style of most other histories of the revolt, which are often based on the British narrative of the events. This seems to be an imposed, easily-classified narrative of the revolt which diverts focus from the subaltern's own historical memory of the same time period. Since Ghandour strives to write a subaltern history, and admits that such histories are often based on collective memories rather than official documents, it would have been helpful to analyse the years of 1936 to 1939 on a non-official basis.

It is popular to term the time from the general strike to the Peel Commission Report as a first phase of revolt, the tactic of killing British officials and deportation of Higher Committee members as the second phase, and emergence of the Peace Bands to the crushing of the resistance as the final phase. These phases are constructed around the level of violent resistance, and in dividing them in this way, the author neglects what other historians have also failed to emphasise: the use by populist leaders, including men like Akram Zu'aytir, 'Izzat Darwaza and 'Awni 'Abd al-Hadi, of social organizations, student groups, sports clubs, schools, other secular and religious societies, and public spaces to push an initially effective non-violent call for an end to the Mandate and establishment of national government and citizenship rights.

Ghandour devotes considerable space to the Palestinian rebel himself as a peasant Arab, and juxtaposes the language he used to express values, identity, activism, and memory with the British official discourse on the rebels. This is the most important feature of the book because Ghandour chose not to use an imposed narrative form to write history but rather to write this particular history of domination and colonialism in the words of those whom it impacted. Again, Ghandour does not mince words with regard to whom the rebels blamed for the Revolt and its aftermath, as well as for the Revolt's use of violence to achieve the end of British administrative rule. Ghandour effectively paralleled her use of the British documents to shed light on the truth of one rebel's claim that "the English turned justice into injustice and injustice into justice" (p. 114).

It is, of course, standard practice to show the Mandate's political history as impacted heavily by Palestinian elite and British official favouritism reflected in the granting of salaried positions to men in the families of the Grand Mufti, the Husseinis, and their so-called rivals in Jerusalem, the Nashashibis. Ghandour takes this traditional narrative in the fourth chapter " "Raising of the Religious Cry': How to Make Muslims, Moderates and Extremists out of the Elite" as an example of the need - and nothing more - of British officials and historians to familiarise themselves with Palestinian politics as a factional affair and to then apply themes of nationalism versus collaboration to those politics. This is important to remember, Ghandour tells us, since this mindset guided the policies of the Palestine 
Administration and officials in London and their understanding of what institutions the Palestinians needed. Documents studied by Ghandour, including those produced by the British Colonial and Foreign Offices through the first twenty years of the Mandate, clearly show the Administration's unease with and consequent non-recognition of the secular Muslim-Christian societies and the Executive Committee of the Palestinian Arab Congress and the reasons behind the Administration's support for the Supreme Muslim Council in order to prevent a (non-existing) Muslim backlash to mandatory rule.

The entire work uses new archival and oral sources, while lending fresh eyes to British sources. Importantly, Ghandour adds many Palestinian voices to this history, with a prominent example of this being her use of a diary, published for the first time, of one particular Jerusalemite notable's exile to the Seychelles after the outbreak of the Revolt. I would have liked to see the words of a non-notable concluding the book. Even so, exile of Palestinians during the Revolt is a little-discussed part of Mandate history. Many individuals, because of allegiances, were forced out of Palestine, though it is true only elite letters and diaries of experiences exist in the archives. Yet elite or not, this discussion of political exile by a Palestinian offers an anti-colonial view of Palestinian history rarely published in English. Ghandour succeeds on several fronts with this book and inaugurates a new direction in the study of internationally-sanctioned colonialism in the Arab Middle East. 